\title{
First record of Protaetia (Netocia) subpilosa (Coleoptera: Scarabaeidae: Cetoniinae) in Romania
}

\author{
Maximilian Teodorescu ${ }^{1}$ Leonard Drapau ${ }^{2}$
}

115 Fizicienilor, L2 Block, Apartment 7, 077125 Măgurele, Romania

2200 Calea Griviței, A Block, Apartment 78, 010755 Bucharest, Romania

Corresponding author: Maximilian Teodorescu (tmaxim@spacescience.ro)

Received 28 February 2020 | Accepted 6 May 2020 | Published 30 June 2020

Citation: Teodorescu M, Drapau L (2020) First record of Protaetia (Netocia) subpilosa (Coleoptera: Scarabaeidae: Cetoniinae) in Romania. Travaux du Muséum National d’Histoire Naturelle “Grigore Antipa” 63(1): 79-82. https:// doi.org/10.3897/travaux.63.e51588

\begin{abstract}
A new species for the Romanian entomofauna is mentioned: Protaetia (Netocia) subpilosa (Desbrochers des Loges, 1869).The only found individual is illustrated, and its habitat is discussed.
\end{abstract}

\section{Keywords}

First record, Protaetia subpilosa, Romania.

About nineteen species of Cetoniinae are known from Romania (Löbl I 2016), with a greater diversity in the southern part of the country, where some of them reach their northern geographic limits.

Protaetia (Netocia) subpilosa (Desbrochers des Loges, 1869) is a wide spread species, with two recently described subspecies: Protaetia subpilosa dorchini (Legrand \& Drumont, 2006) and Protaetia subpilosa iranica (Montreuil \& Legrand, 2010).

The nominotypical subspecies is known from Bulgaria, Turkey, Greece, Jordan, Lebanon, and Syria (Löbl 2016). From Bulgaria it is known from just two localities: from Narechenski Bani (Asenovgrad area) (Bunalski 2001) and Isperihovo area (Ziani et al. 2015). At both localities there were only a few individuals found, and this is most likely due to the low density of local populations. Also, P. subpilosa habitus is at first glance somehow similar to Protaetia hungarica (Herbst, 1790), and 
this might also be one of the reasons why there are only sporadic observations of the species.

The larvae of this species have been observed at the base of Onopordum, Echinops and Cirsium plants (Tauzin 1993).

Due to being a widespread species and with the known localities in Bulgaria not too far from the Romanian territories, its presence in Romania was not to be considered as unlikely, especially in Southern Dobrogea.

As such, one male individual was found and identified by the second author on June 12, 2019 in the area of the Canaraua Fetii, on the side of the road that passes from the village of Baneasa towards the northern exit of the reservation, at coordinates $44.0566^{\circ} \mathrm{N}, 27.6514^{\circ} \mathrm{E}$, altitude: $25 \mathrm{~m}$. A photograph of the habitat is shown in Figure 1. The specimen was found feeding on Onopordum tauricum Willd., 1803 (Asteraceae), alongside with two individuals of Cetonia aurata (Linnaeus, 1758). All were feeding on the inferior parts of the plant buds, and were hidden by leaves.

The individual was identified as Protaetia subpilosa var. pseudocupricollis (Tauzin, 1993), with less obvious white spots on the elytra, and a copper-green hue on the pronotum. Photographs of the specimen are presented in Figure 2, where the aedeagus is also shown. The male individual is stored in the personal collection of the second author.

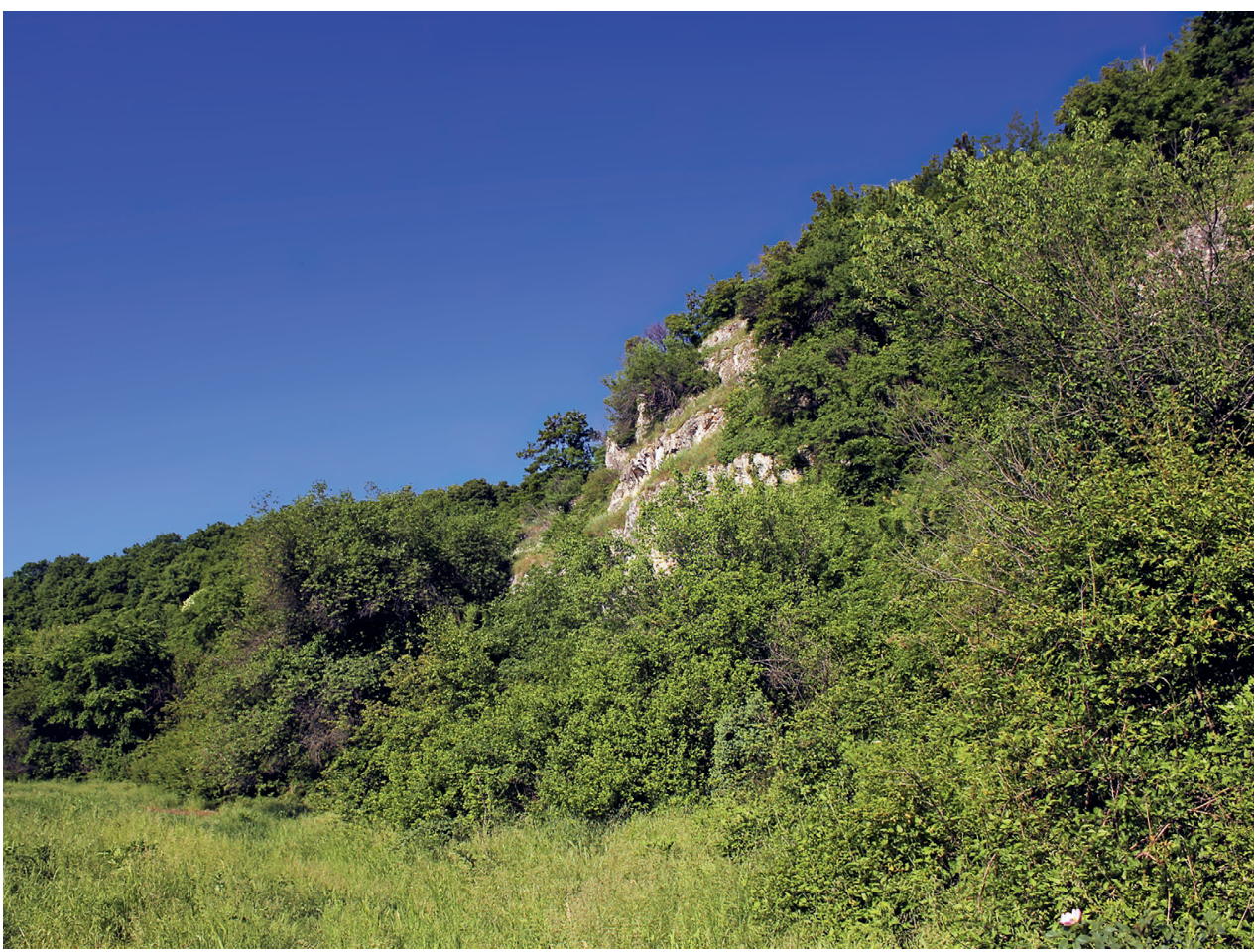

Figure 1. Habitat of P. subpilosa in the Canaraua Fetii area. 


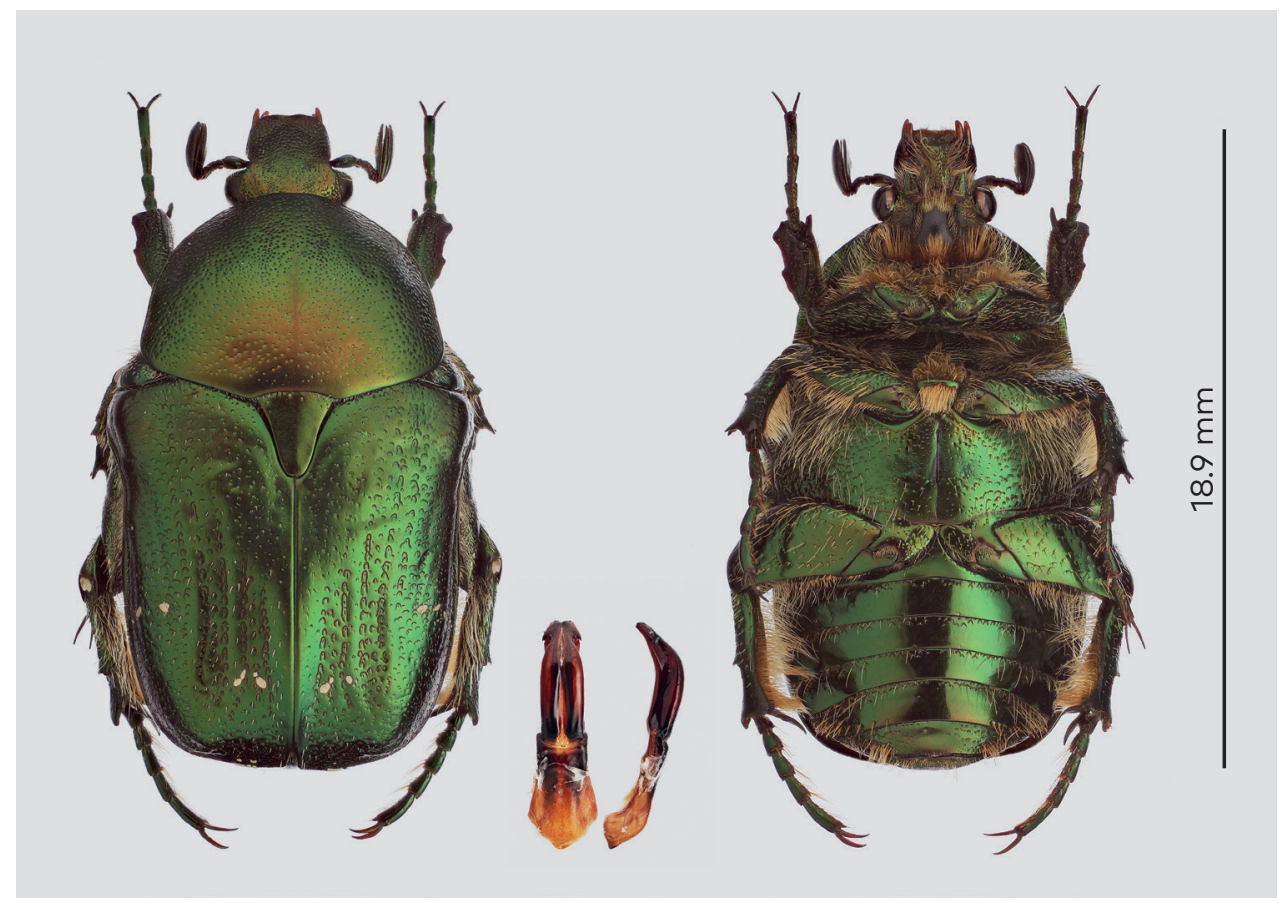

Figure 2. Habitus of P. subpilosa. Aedeagus also shown.

The Canaraua Fetii dry valley is situated on the border with Bulgaria and starts near the small village of Baneasa, not far from Oltina Lake. From here it passes south into Bulgaria and continues for a long distance inside the country. This virtual path is a possible way the species can reach the Romanian territories, as the host plants for the larvae are present mostly in the fields close to the calcareous walls of the valley.

In order to assess the abundance of the species in the area, future field work will focus on finding larvae and/or cocoons buried in the proximity of the plants (Onopordum sp.), and also actively searching for adults on the plants themselves.

\section{References:}

Baraud J (1992) Coléoptères Scarabaeoidea d'Europe [European Scarabaeoidea Coleopterans]. Féderation Française des Sociétés de Sciences Naturelles. Faune de France 78, 856 pp. [in French]

Bunalski M (2001) Contributions to the knowledge Scarabaeoidea (Coleoptera) of Bulgaria. Part II. Species not recorded from Bulgaria before. Wiadomości Parazytologiczne 20: 29-32.

Löbl I, Löbl D (2016) Catalogue of Palaearctic Coleoptera, Volume 3. Brill, 984 pp. 
Tauzin P (1993) Précisions sur la répartition de quelques espèces de Cetoniinae Paléarctiques. Troisième note: Les Netocia Costa, 1852 [Details on the distribution of some Palearctic Cetoniinae species. Third note: The Netocia Costa, 1852]. L'Entomologiste 49: 145-172. [in French]

Ziani S, Bezdek A, Branco T, Hillert O, Jákl S, Král D, Mantič M, Rößner E, Sehnal R (2015) New country records of Scarabaeoidea (Coleoptera) from the Palaearctic Region. Insecta Mundi 409: 1-36. 